\title{
Outlook for the biomass energy sector in Mozambique: Policies and their challenges
}

\author{
Jonas Massuque ${ }^{1,2}$ iD, Custodio Matavel ${ }^{1,3 *}$, Paulo Fernando Trugilho ${ }^{2}$ \\ 1. Faculty of Agrarian Sciences, Lúrio University, Campus Universitários de Unango, Mozambique \\ 2. Department of Forest Sciences, Federal University of Lavras, Brazil \\ 3. Leibniz Centre for Agricultural Landscape Research, Müncheberg, Germany
}

\begin{abstract}
To overcome the negative impacts of unsustainable exploitation offorest resources, the Mozambican government has been trying to regulate the supply and demand of biomass, the main source of energy for the majo rity of the population. This paper reviews policies implemented in Mozambique aimed at increasing domestic energy production while promoting a sustainable use of biomass. Despite the efforts to reduce the level of biomass energy use, it remains the most attractive to local populations and, therefore, still has great importance in the national energy mix. Thus, rather than looking at woodfuels as an environmental problem, regulations should also recognise the dependence of local communities on these resources. Firewood remains the main energy source in rural areas, and approximately $0.36 \%$ of the forest in Mozambique is lost every year. The replacement of firewood and charcoal by other renewable sources of energy is still far from reality. Charcoal production continues to be carried out in traditional low-yield ovens and the levels of forest degradation are still alarming. As such, improvements to the existing regulation framework are still needed.
\end{abstract}

Keywords: energy policy; renewable energy, unsustainable exploitation, woodfuel

\section{Highlights}

- Woody biomass remains the most attractive energy source in Mozambique.

- The government implemented policies to address unsustainable use of biomass.

- The policies did not lead to a sustainable use of biomass.

- Policy design should consider both technical and socio-cultural aspects.

Journal of Energy in Southern Africa 32(4): 1-10

DOI: https://dx.doi.org/10.17159/2413-3051/2021/v32i4a11936

Published by the University of Cape Town ISSN:2413-3051 https://journals.assaf.org.za/jesa

This work is licensed under a Creative Commons Attribution-ShareAlike 4.0 International Licence

Sponsored by the Department of Science and Innovation

Corresponding author:Email: custodiomatavel@gmail.com 


\section{Introduction}

The conservation of forest resources has received great attention from the Mozambican government. In April 2020, it announced the suspension of logging licences issuance for two years, as a way of reducing pressure on the forests (GdM, 2020). But this may not be effective if it is not accompanied by other measures, considering that, on the one hand, more than half of the exploitation of forest resources in Mozambique is illegal (EIA, 2013; Magalhães, 2014; Wertz-Kanounnikoff et al., 2013), and, on the other, meeting the energy needs of the population in Mozambique depends largely on forest resources (Cuvilas et al., 2010; Brouwer and Falcão, 2004; Batidzirai et al., 2006), whose consumption levels tend to increase (Brouwer and Falcão, 2004), due to the high population growth rate (HPP, 2015; Smith et al., 2019). In fact, the number of people dependent on biomass energy, especially among rural poor households in sub-Saharan Africa, is expected to rise (Owen et al., 2013). Thus, the legislation regulating biomass energy sector should not focus only on the downsides but should also look at fuelwood production as part of sustainable development.

There are two sectors that regulate the supply and demand of forest resources in Mozambique, the agricultural sector and the energy sector. The former focuses on the supply of raw materials and is regulated by the Forest and Wildlife Law and the Land Law. The latter is focused on the demand for raw materials and is guided by the Energy Policy and Strategy, New and Renewable Energy Development Policy, Biofuels Policy and Strategy, and the Strategy for Biomass Energy Conservation and Sustainable Use. Nevertheless, the effectiveness and implications of these policies are still not clear. Many actions intended to develop and secure energy access appear to have several gaps (Cuvilas et al., 2010). For example, biomass energy has re- ceived a limited degree of intervention from the energy sector, although the importance of this energy source in the context of Mozambique has already been demonstrated (ME, 2013). Moreover, the responsibilities related to energy issues are divided between different government sectors. This generally leads to administrative difficulties in implementing the policies and planned proposals.

Policies and strategies that regulate the biomass energy sector in Mozambique are quite recent and still present challenges, such as the lack of structuring mechanisms to guarantee their implementation and effective functioning. In biofuels, for example, the policies do not establish restrictions on the type of raw materials, a situation that may open space for future conflicts between food security and the production of biofuels (Matavel and Chaves, 2015). In addition, none of the policies establish the type of technology suitable for charcoal production to guarantee energy efficiency and sustainability of natural resources. Hence, this study reviews the legal framework surrounding the supply and demand of biomass energy in Mozambique in order to improve the understanding of their dynamics, and discusses the future direction for policy design and implementation in order to secure a more effective and sustainable exploitation of natural resources.

\section{Overview of the energy sector in Mozambique}

Figure 1 displays estimates of the share of energy sources in the production of energy in Mozambique from 2007 to 2017. According to this figure, after a decrease in 2008, energy production has been increasing since 2009. The first gas plant was establishment in 2012 and the supply of natural gas has increased from 2013. In 2014 three more power plants started to operate, thus, the gas supply further increased (ALER, 2017). The production of coal started to take place also in 2013. After a significant

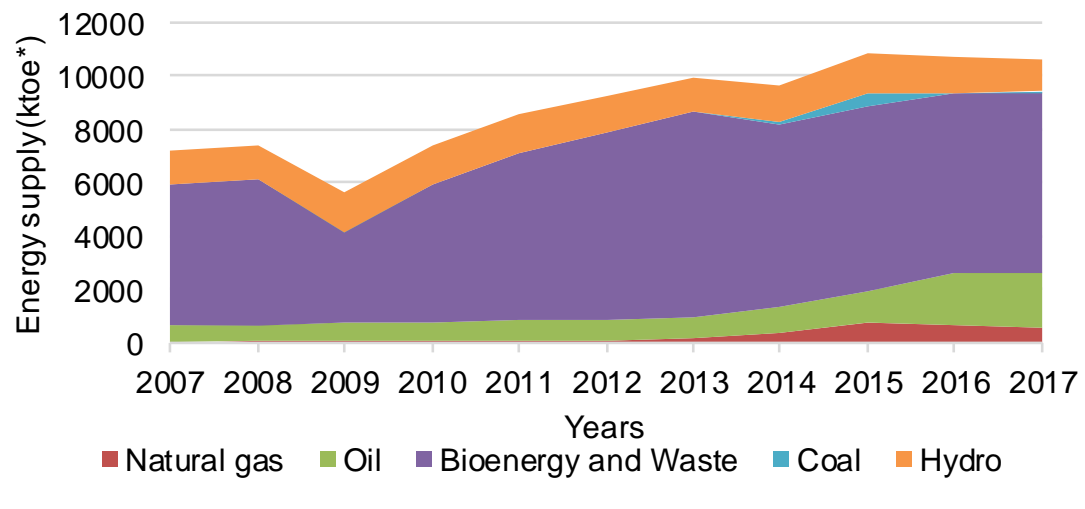

Note: $* 1$ ktoe $=11628000 \mathrm{kWh}$

Figure 1: Total primary energy supply in Mozambique by source, 2007-2017

Source: IEA (2018) 
growth from 2014 to 2015, this sector declined due to economic crisis in 2016 (WB, 2017). Woody biomass has remained relatively consistent over the years as the main source of energy. Only hydroelectric energy and biomass currently contribute to the consumption of renewable energy in Mozambique. There are no data available regarding the use of wind and solar energies.

As shown in Figure 1, bioenergy and waste, which include biomass, are the largest sources of energy. This scenario has also been reported in several studies (Broto et al., 2018; Woollen et al., 2016; Mahumane and Mulder, 2019). In fact, the rate of forest degradation in Mozambique is about 0.36\% per year (Aquino et al., 2018) and its main drivers include forest extraction for biomass energy (particularly charcoal for urban use) and unsustainable logging (Sitoe et al., 2016). Estimates by Silva et al. (2019) indicate that, under current conditions of charcoal production, the annual aboveground biomass extraction rates will gradually increase from $0.3 \%$ to $0.7 \%$ between 2015 and 2040 . Therefore, it is necessary to create alternative sources of income for households engaged in the production and sale of charcoal. Moreover, consistent and effective law enforcement is urgently needed in order to remove the barriers in accessing clean and sustainable energy and minimise the problem of forest degradation (Baumert et al., 2016). The following sections discuss the policies and strategies that were developed to ensure the supply of energy while promoting a sustainable exploitation of forest resources.

\section{Fuelwood energy demand and supply dynamics}

As widely noted, woodfuels from natural forests are the main sources of energy for domestic purposes in Mozambique (Broto et al., 2018; Cuvilas et al., 2014; Falcão, 2008). In fact, more than $80 \%$ of households use woodfuels - which includes firewood and charcoal - for cooking (Falcão, 2013). Charcoal is mainly used in urban areas in relatively high-income households (Broto et al., 2020) and firewood is mainly used in rural areas (approximately 98\%) (Sitoe et al., 2007). As such, urban consumption of woodfuels is more likely to cause deforestation (Sedano et al., 2016) since efficiency of charcoal production in Mozambique ranges from $10 \%$ to $25 \%$ (Falcão, 2008). The annual per capita consumption of woodfuels in urban areas is estimated at 1.96 tons, and in rural areas at 0.695 tons (Sitoe et al., 2007). There is an increasing trend of woody biomass energy consumption. For example, from 1988 to 2007, Maputo province registered an increase in the average annual consumption of woodfuels from $0.82 \mathrm{~m}^{3}$ to $1.16 \mathrm{~m}^{3}$ per household (Sitoe et al., 2007). According to Fernandes (2014), despite rural consumption of wood energy being $76 \%$ of the national figure (9.1 million tons/year) it is less likely to affect the functional structure and composition of native forests, as rural dwellers usually harvest the branches or pieces of dead trees.

It can be argued that rural dwellers' livelihoods (employment, income, consumption of goods and services) depend on natural forests and are directly linked to the purchasing power of the urban population, since charcoal is mainly produced in rural areas and consumed in urban areas (Atanassov et al., 2012; Arthur et al., 2010; Castán Broto et al., 2018; Baumert et al., 2016; Smith et al., 2019). Thus, the growing population and increased firewood and charcoal consumption in urban areas (Atanassov et al., 2012; Sedano et al., 2016), as well as the low efficiency of charcoal production, are likely to exacerbate the exploitation of natural resources.

\section{Policies for the biomass energy sector 4.1 Policy and strategy for the energy sector}

The energy policy approved by Resolution No. 05/98 of March 3rd (GDM, 1998) aims at ensuring the reliable supply of energy, at the lowest cost, to meet consumption needs and socio-economic development. With regards to biomass energy, this policy emphasises the use of firewood and charcoal and does not approach the use of liquid or gaseous fuels. Nevertheless, there was a concern on the part of the government to establish energy plantations and gradually reduce the use of fuelwood by promoting the use of natural gas and coke.

Mozambique has two natural gas reserves, one in Inhambane Province, the other in Cabo Delgado Province. The reserves in the Rovuma Basin (Cabo Delgado) have 127.4 billion $\mathrm{m}^{3}$ of natural gas (Vaz et al., 2011), which makes it the fourth largest reserve in the world. Coal reserves are estimated at 23 billion tonnes (ALER, 2017), also one of the largest in the world (Suárez and Borras, 2010). Among the different sources of energy available in the country, natural gas registered the highest average annual growth rate between 2005 and 2014 (23\%) (ALER, 2017). However, although Mozambique has great potential for generating energy from fossil energy sources, the growth in the use of these energy sources is not available to low-income households, which puts at risk the intended reduction in the demand for firewood and charcoal. Access to electricity is also far from reducing the demand for firewood and charcoal (Broto et al., 2018). Although Mozambique is one of the largest producers of electricity in the southern region of Africa (surpassed only by South Africa), only $20 \%$ of the population has access to electricity (Nhamire and Mosca, 2014 ), with an annual growth rate of around 3\%. The capital Maputo is responsible for $75 \%$ of all electricity consumption (ALER, 2017). 
In 2009, the new Energy Strategy came into force, approved by Resolution No. 10/2009 of June $4^{\text {th }} 2009$ (CDM, 2009b). This strategy was motivated by the new national panorama of the emergence of new fields of action, such as the production and the use of biofuels, and the constraints imposed by the international oil market at that time. The strategy highlights the importance of energy security, efficiency improvement, energy waste reduction, research and technological innovations.

At this stage of understanding, we believe that timely investment in the production of electricity from the available sources (e.g. gas and coal) can reduce the cost of electricity and reduce the negative impacts of forest resources exploitation. Access to electricity produced by these sources will represent a significant improvement in the quality of rural communities' life, when compared to the use of firewood and charcoal, and will cause the diversification of the national energy mix. However, the policy and strategy of the energy sector seem to not have been effective in improving access to energy in the country, especially in rural areas, since woody biomass has remained the main source of energy.

\subsection{New and Renewable Energy Development Policy}

The New and Renewable Energy Development Policy (NREDP) was approved by Resolution No. 62/2009, of October 14th (CDM, 2009a). The main objectives of the policy are 1) to promote the provision of good quality renewable energy services at affordable prices, especially in rural areas; 2) to promote the use of renewable energy sources; 3 ) to strengthen energy security at local and national levels; and 4) to reduce negative environmental impacts at local and global levels. Renewable energy policies should aim, among other things, to overcome the high cost of certain technologies and the low acceptance by consumers when a new technology is introduced (IRENA et al., 2018). However, national energy policies regulate the price of all energy sources except fuelwood. Only the charcoal producers have to pay some fees, to get a licence to harvest wood. Charcoal in urban markets in Maputo costs around MZN 900 (USD 30) for a $50 \mathrm{~kg}$ container (Baumert et al, 2016), which equals about $20 \%$ of the minimum monthly wage in the country. Although NREDP's objective is to guarantee affordable prices, the cost of energy in the country is too high for most consumer.

As recognized by the policy itself, the new and renewable energy sub-sector in Mozambique is in its initial stage of development and lacks adequate structure and mechanisms for its growth. Therefore, there is still a need to establish adequate mechanisms to study the potential of these forms of energy. Of all energy sources, only biomass has been widely studied (e.g. Batidzirai et al., 2006; Brouwer and Falcão, 2004; Vasco and Costa, 2009). As such, it appears that Mozambique is still a long way from exploring the full potential of renewable energy sources, given that, although this policy is aimed at new and renewable energy sources, it states that these sources can be combined with nonrenewable energy sources to form so-called hybrid systems. Such systems, it is suggested, can be more advantageous than those based exclusively on new and renewable energy sources, especially in situations where the inclusion of non-renewable fuels improves access to energy services, reducing the cost of energy supply.

So far, only biomass has a specific regulatory platform; specific strategies for other sources (solar, wind, small-scale, oceanic, among others) have not yet been developed. This is due to the fact that of all renewable energy sources, only woody biomass is widely used. Therefore, there is a need to explore other energy sources in order to relieve the pressure on biomass.

\subsection{Biofuels Policy and Strategy}

The Biofuels Policy and Strategy was approved by Resolution No. 22/2009 of May 21st. It is a legal instrument that defines the policy guidelines and measures of greatest relevance for the biofuels sector, in addition to providing guidelines for the production, consumption and commercialisation of biofuels. Sugarcane and sorghum were selected as potential crops for ethanol production and jatropha and coconut for biodiesel production.

The Resolution does not establish restrictions on raw materials, which may create the potential for competition between food security and the production of biofuels (Renzaho et al., 2017). The use of food crops for biofuel production establishes competition for fertile land, causing food insecurity as well as leading to increased agricultural production costs (Mohr and Raman, 2013; Murphy et al., 2011). As such, a central recommendation is that biofuel production must also be included in the country's agrarian policy and it is necessary for the law to establish non-food energy crops that adapt to marginal soils. A new agricultural development model that ensures the simultaneous production of food and energy crops could guarantee the diversification of the income of rural communities, generating employment and self-employment in agriculture and agro-industrial processing sectors.

In Mozambique, although the plans for their largescale production are underway, the production of liquid biofuels is still marginal (Cuvilas et al., 2010), probably due to technological limitations (Scrase et al., 2009) and the fact that renewable energy options often require high initial investments (Shenoy et al., 2011). In addition, biofuels supply does not 
meet the existing demand (Avinash et al., 2014), but nevertheless seem to be used to substitute for electricity and liquefied petroleum gas rather than charcoal and firewood (Mudombi et al., 2018). So there is still a strong dependence on firewood and charcoal (Cuvilas et al., 2010), which is linked to crucial development issues, such as deforestation and poverty (Martins et al., 2018).

\subsection{Forest and Wildlife Law}

The Forest and Wildlife Law (FWLL), Law no. 10/99 of July 7 (GDM, 1999), establishes that commercial extraction of wood from natural forests for energy purposes is carried out after the presentation of a sustainable management plan and payment of the forest exploitation fee. The management plan is based on the forest inventory with distribution of diametric classes. A study of regeneration and the harvest must be organised by means of a cutting system, which specifically guarantees and promotes the regeneration of forests, establishing a system of selective cuts and minimum cut diameter by species.

A substantial part of the law does not cover local communities as long as they exploit resources for their own consumption in accordance with their customary rules and practices. However, the use of firewood and charcoal for self-consumption is part of the customs of communities across the country (Atanassov, 2010) and exploitation limits for local communities are not presented in this law. The extraction of wood for self-consumption is also stimulated by the very limited access to electricity and low purchasing power of rural people who cannot afford alternative energy sources (Arthur et al., 2010).

The FWLL regulation establishes that the main product of forest species producing precious wood $\left(1^{\text {st }}, 2^{\text {nd }}\right.$ and $3^{\text {rd }}$ classes $)$ as well as rare or protected woods or those with historical or socio-cultural value must not be used for the production of firewood and charcoal (CDM, 2002). However, it does not specify the criteria used to classify these species, nor the properties of the wood destined for energy use. Furthermore, issues related to reforestation, afforestation and deforestation appear to be outside the scope of the FWLL. Its Regulation simply mentions, in Article No. 80, that 'any natural or legal person interested in establishing forest plantations for conservation does not require environmental impact assessment'. Therefore, this law does not seem to be adequate to solve problems related to forest exploitation, adequate use of wood or forest replacement, among other aspects that can contribute to the reduction of rural poverty. Moreover, weak monitoring of exploitation and weak law enforcement are also important shortcomings of the FWLL (Baumert et al., 2016)
From 2007 to 2018, there was a 21\% decrease of the total forest area and 36\% of the productive forest area (MITADR, 2018). Inequalities exist between rural and urban areas (Gradín and Tarp, 2019). The poverty rate in rural areas is estimated at more than $50 \%$ and in urban area at $37 \%$ (Navarra and Udelsmann Rodrigues, 2018; Martinez et. at, 2017), although $20 \%$ of any forestry or wildlife exploitation fee is earmarked for the benefit of communities in the area where the resources were extracted (CDM, 2002). This amount should be transferred to the community on an annual basis, but only benefits people with a certain level of power within the community (Massuque et al., 2019). This situation might encourage illegal logging and the cover up of illegal loggers by rural communities.

\subsection{Strategy for conservation and use of biomass energy}

The strategy for the conservation and sustainable use of biomass energy, approved in November 2013, aims to promote the production and sustainable use of woody biomass energy through the adoption of alternative energy sources, thus contributing to energy security in the domestic and industrial sector. This constitutes one of the instruments for the materialisation of the New and Renewable Energy Development Policy (GDM, 2013).

Two actions established in this strategy are (1) the definition of measures to conserve wood fuel consumption, through the improvement of carbonisation and combustion techniques, and (2) the introduction and promotion of efficient technologies for the use of biomass, such as improved stoves. However, the level of adoption of improved stoves is still low (Catalán-Vázquez et al., 2018; Atanassov, 2010; Kapfudzaruwa et al., 2017). Regarding the carbonisation of wood, the implementation of more advanced furnace technologies for the production of charcoal in the cities of Maputo, Beira, Nampula and Matola resulted in an increase in yield of up to $32 \%$ compared to traditional ovens (Atanassov et al., 2012). However, a large part of charcoal production continues to be carried out in traditional lowyield furnaces. Moreover, the strategy does not establish the type of technology suitable for charcoal production in order to ensure energy efficiency and sustainability of forest resources.

The introduction of alternatives to charcoal in the market, such as briquettes and pellets, can cause problems in terms of consumer acceptability (Mwampamba et al., 2013). To overcome this, it is desirable to use a strategy that highlights the qualities of the new product and that is preceded by an evaluation of its effectiveness, as attempted by Vesterberg (2014). However, studies on the effect- 
iveness of these alternative sources to charcoal in Mozambique are almost non-existent, so there is still no scientific evidence to support such choices. Technological, economic and market studies must be carried out to guarantee the quality of the new product, income distribution to the population and satisfaction of the final consumer.

\subsection{Land Law}

The Land Law, Law no. 19/97 of October 1st (GDM, 1997), is extremely important for the energy sector, since the implementation of energy projects depends on the concession of land by the government, which owns it inalienably. The Land Law creates adequate structural elements so that, by granting the right to use and benefit from land (DUAT) on public lands (state reserves), people can establish forest plantations for energy purposes. However, there is no mention of issues related to the use of forest resources for energy production. Furthermore, the use of land can be exercised even in the absence of a legal title, provided that natural persons and/or local communities have been using the land for at least ten years, in accordance with customary norms and practices.

Mozambique has been an example of continuous deforestation and degradation and the exploitation of energy resources has always been on the list of causes (Mucova et al., 2018; Tokura et al., 2020; Sedano et al., 2016). Decree No. 25/2020 of May 5, 2020 (GDM, 2020), suspends logging under a simple licence and concession regime, to reduce deforestation and promote recovery of ecosystem services in natural forests. Moreover, the opportunity arises for the introduction of energy plantations in the country with fast-growing species, since the Land Law in article 29 establishes the free use of land for small-scale agricultural purposes by local communities. The use of land for energy plantations can be a viable alternative for diversifying the income of communities members in the future, as well as reducing the pressure on natural forests in the search for wood fuels (Lenz et al., 2019).

For investors, the DUAT allocation process is complex, passing first through the allocation of provisional DUAT in a period of two and five years for foreign and national investors respectively. The definitive DUAT is only issued after monitoring and evaluation of the exploration plan proposed by the investor and the submission of the Environmental Licence. The government needs to reduce bureaucracy in the DUAT acquisition processes and strengthen the management and monitoring capacity of land legislation, due to the risk of losing investment projects (Matavel and Chaves, 2015). As stated by Aquino et al. (2018), insecurity in land ownership discourages investment in long-term as- sets with limited and non-immediate returns, including forests and other natural resources. In 2014, Floresta do Planalto, a company from the Finnish group UPM, announced the withdrawal of its investment in the eucalyptus reforestation sector in northern Mozambique, due to the lack of land for new plantations (Blid, 2014). However, the local government reiterated the existence of land for new plantations, blaming the delay on the complexity of the DUAT allocation process for investments in the forestry industry.

It is important to define 'local community', as it may determine whether or not disputes exist between traditional forest users (local communities) and private investors, as well as the extent of exploitation and sustainability of forest resources. 'Local community' is defined in the Land Law as a 'group of families and individuals, living in a territorial circumscription at the level of locality or below, which aims to safeguard common interests through the protection of housing areas, agricultural areas, whether cultivated or under fallow land, forests, sites of cultural importance, pastures, water sources and expansion areas' (GDM, 1997). The Law recognizes and protects land tenure for indigenous peoples and local communities. However, there seems to be inconsistency between formal and informal land rights and it is not clear whether being a member of the community is about descent or is based on residence; that is, it is not clear whether immigrants are also legitimate members of the community and therefore have the right to use and benefit from the land. This can hinder the legitimation of users of natural resources within the community, which can increase the number of cases of conflicts, as reported in several studies (Bleyer et al., 2016; Bruna, 2019; Baumert et al., 2019; Filipe and Norfolk, 2017; Kosenius et al., 2019), and can increase the number of explorers, increasingly undermining the sustainable use of resources.

\section{Future perspectives}

In the context of Mozambique, biomass is a common good, but it is also a commercial product that most households depend on. Moreover, there is still a grey area on the differentiation between fuelwood production for household consumption and production for commercial purposes, and this vagueness, in addition to the current regulation on taxation mechanisms, favours illegal logging. In general, it is much cheaper to produce illegally than legally and sustainably. Therefore, while strategies are being created to reduce the consumption of this energy source, there must also be efforts for greater regulation, inspection and control of the biomass energy market, in order to avoid the large physical and financial losses that occur along the chain of 
value. In addition, in the case of charcoal, mechanisms should be created to discourage illegal production and promote efficient production with improved techniques that can reduce wood consumption. The majority of producers engaged in charcoal production operate outside existing government regulation, since the current regulations frame fuelwood production as an environmental problem and not as a rural livelihood activity, and therefore the formal licensing of charcoal is currently unlikely, especially to small producers, who are often marginalised (Jones, 2017). Thus, biomass energy should be considered as an economic opportunity to local communities and not only as a threat to forests, in order to facilitate the formalisation of biomass energy production.

The centralised resource management system in Mozambique can create a situation where local communities do not see themselves as owners of the resources and therefore responsible for the sustainable management of forest resources on their land. In fact, despite land abundance there are concerns over land-grabbing and dispossession of rural communities in Mozambique (Cabral and Norfolk, 2016). Therefore, there is a need for decentralis ation of natural resource management to encourage stakeholders' engagement. Local actors should be provided with sufficient technical, organisational, financial and human resources to ensure the proper management of natural resources. The licensing system must involve local communities in order to ensure better enforcement of licensing rules and greater control over producers, and government strategies for forest management should be in line with local communities' livelihoods.

Policy makers should be aware that, if a certain policy measure is not effective, it is not because the communities do not understand the need to shift toward more sustainable and clean energy production and consumption. Rather, it is because the policy is not well adapted to people's needs. For example, a programme aiming at replacing traditional stoves by cleaner and more efficient ones may not be successful simply because the new stoves may not fit into their culture (Victor, 2011). Thus, it is important to consider socio-cultural aspects when designing a policy and to emphasise aspects that are intrinsically appealing to people, rather that only focusing on technical aspects.

\section{Conclusions}

The present review showed that in Mozambique, although the government recognises the need to enhance the use of renewable energy sources, the regulations on renewable energy focus more on the biomass energy sector. The aim is to reduce the use of woodfuels, but there is still lack of affirmative evidence that supports the use of alternative sources of energy as intended.

Although the various legal instruments are complementary, the implementation of the laws in force seems to be ineffective, since after more than 20 years of legislation, the levels of forest degradation are still alarming, firewood remains the prevalent energy source in rural areas, and charcoal production continues to be carried out in traditional lowyield ovens. Such facts significantly aggravate the waste of woody material and the lack of control over the use of forest resources.

Multiple challenges need to be overcome to reduce socio-economic losses due to the poor alignment between the current legal framework and the needs of local communities, which largely depend on forest resources for their livelihood.

\section{Author roles}

Jonas Massuque and Custodio Matavel contributed to the conceptualization, searched and interpreted the relevant policies and literature, and wrote the first draft of the manuscript. Paulo Fernando Trugilho commented and critically revised previous versions of the manuscript. All authors read and approved the final manuscript.

\section{Acknowledgements}

This research was supported by the Ministry of Science and Technology, Higher, Technical and Professional Education (MCTESTP-MOZAMBIQUE, Process nํ 37.01. 2015), Coordination for the Improvement of Higher Education Personnel (CAPES-BRAZIL, Process no 88881. 284250/2018-01), the National Council for Scientific and Technological Development (CNPq), the Research Support Foundation of Minas Gerais State (FAPEMIG) and the Biomaterials and Biomass Energy Laboratory from Federal University of Lavras. We would like to thank the anonymous reviewers for commenting on earlier versions of this article.

\section{References}

Associação Lusófona de Energias Renováveis [ALER] 2017. Renewables in Mozambique - National status report, second edition. Lisbon, Portugal: ALER.

Aquino, A., Lim, C., Kaechele, K. and Taquidir, M. 2018. Notas sobre a floresta em Moçambique. Maputo: World Bank Group.

Arthur, M. D. F. S. R., Zahran, S. and Bucini, G. 2010. On the adoption of electricity as a domestic source by Mozambican households. Energy Policy, 38 (11): 7235-7249.

Atanassov, B. 2010. Socio-cultural dimensions in household cooking energy choice: Implications for energy transition in Catembe, Mozambique. Independent thesis Advanced level (degree of Master (Two Years)) Student thesis, Stockholm University, Sweden. 
Atanassov, B., Egas, A., Falcão, M., Fernandes, A. and Mahumane, G. 2012. Mozambique urban biomass energy analysis 2012. Maputo: Mozambique Ministry of Energy.

Avinash, A., Subramaniam, D. and Murugesan, A. 2014. Bio-diesel-A global scenario. Renewable and Sustainable Energy Reviews, 29:517-527.

Batidzirai, B., Faaij, A. P. C. and Smeets, E. 2006. Biomass and bioenergy supply from Mozambique. Energy for Sustainable Development, 10(1):54-81.

Baumert, S., Fisher, J., Ryan, C., Woollen, E., Vollmer, F., Artur, L., Zorrilla-Miras, P. and Mahamane, M. 2019. Forgone opportunities of large-scale agricultural investment: A comparison of three models of soya production in Central Mozambique. World Development Perspectives, 16:100145.

Baumert, S., Luz, A. C., Fisher, J., Vollmer, F., Ryan, C. M., Patenaude, G., Zorrilla-Miras, P., Artur, L., Nhantumbo, I. and Macqueen, D. 2016. Charcoal supply chains from Mabalane to Maputo: Who benefits? Energy for Sustainable Development, 33:129-138.

Bleyer, M., Kniivilä, M., Horne, P., Sitoe, A. and Falcão, M. P. 2016. Socio-economic impacts of private land use investment on rural communities: Industrial forest plantations in Niassa, Mozambique. Land Use Policy, 51: 281-289.

Blid, N. 2014. Indústria florestal e movimento sindical em Moçambique. Maputo: Centro de Solidariedade Sindical da Finlândia (SASK).

Brouwer, R. and Falcão, M. P. 2004. Wood fuel consumption in Maputo, Mozambique. Biomass and Bioenergy, 27(3): 233-245.

Bruna, N. 2019. Land of plenty, land of misery: Synergetic resource grabbing in Mozambique. Land, 8(8): 113.

Cabral, L. and Norfolk, S. 2016. Inclusive land governance in Mozambique: Good law, bad politics? Brighton, UK: Institute of Development Studies.

Broto, V. C., Arthur, M. D. F. S. R. and Guibrunet, L. 2020. Energy profiles among urban elite households in Mozambique: Explaining the persistence of charcoal in urban areas. Energy Research \& Social Science, 65: 101478.

Broto, V. C., Baptista, I., Kirshner, J., Smith, S. and Alves, S. N. 2018. Energy justice and sustainability transitions in Mozambique. Applied Energy, 228: 645-655.

Catalán-Vázquez, M., Fernández-Plata, R., Martínez-Briseño, D., Pelcastre-Villafuerte, B., Riojas-Rodríguez, H., SuárezGonzález, L., Pérez-Padilla, R. and Schilmann, A. 2018. Factors that enable or limit the sustained use of improved firewood cookstoves: Qualitative findings eight years after an intervention in rural Mexico. Plos One, 13(2): e0193238.

Conselho de Ministros [CDM]. 2002. Regulamento da Lei de Florestas e Fauna Bravia. Maputo: CDM.

Conselho de Ministros [CDM]. 2009a. Política de Desenvolvimento de Energias Novas e Renováveis. Maputo: Conselho de Ministros.

Conselho de Ministros [CDM] 2009b. Resolução n.o 9/2009. 9. Maputo: CDM.

Cuvilas, C., Lhate, I., Jirjis, R. and Terziev, N. 2014. The characterization of wood species from Mozambique as a fuel. Energy Sources, Part A: Recovery, utilization, and environmental effects, 36(8): 851-857.

Cuvilas, C. A., Jirjis, R. and Lucas, C. 2010. Energy situation in Mozambique: A review. Renewable and Sustainable Energy Reviews, 14(7): 2139-2146.

Environmental Investigation Agency (EIA). 2013. Conexões de primeira classe: Contrabando, corte ilegal de madeira e corrupção em Moçambique. London, UK: EIA.

Falcão, D. M. S. 2013. Produção e consumo doméstico de combustíveis lenhosos em Moçambique. Masters dissertation, Universidade Nova de Lisboa, Portugal.

Falcão, M. 2008. Charcoal production and use in Mozambique, Malawi, Tanzania, and Zambia: historical overview, present situation and outlook. Proceedings of the Conference on Charcoal and Communities in Africa, INBAR, Maputo, Mozambique, 16 - 18 June, 2008: 20-34.

Fernandes, A. D. M. 2014. Análise da produção de madeira para o fornecimento sustentável de energia doméstica aos centros urbanos de Moçambique. PhD dissertation. Universidade Federal do Paraná, Brazil.

Filipe, E. and Norfolk, S. 2017. Understanding changing land issues for the rural poor in Mozambique. London, UK: International Institute for Environment and Development (IIED).

Governo de Moçambique [GDM]. 1997. Lei de terras. Maputo: GDM.

Governo de Moçambique [GDM]. 1998. Política energética. Maputo: GDM.

Governo de Moçambique [GDM]. 1999. Lei de Floresta e Fauna Bravia. Maputo: GDM.

Governo de Moçambique [GDM].2013. Estratégia de Conservação e Uso Sustentável da Energia da Biomassa. Maputo: GDM.

Governo de Moçambique [GDM]. 2020. Decreto no 25/2020 de 05 de Maio de 2020. Maputo: GDM.

Gradín, C. and Tarp, F. 2019. Investigating growing inequality in Mozambique. South African Journal of Economics, 87(2): 110-138.

Health Policy Project [HPP]. 2015. Mozambique rapid population \& development. Maputo: HPP.

International Energy Agency [IEA]. 2018. Mozambique: Key energy statistics, 2018 [Online]. IEA. Available: https://www.iea.org/countries/mozambique [Accessed 22/06 2020].

IRENA, IEA and REN21. 2018. Renewable Energy Policies in a Time of Transition, IRENA, OECD/IEA and REN21. 
Jones, D. E. 2017. Power of the informal: smallholder charcoal production in Mozambique. PhD dissertation, University of Edinburgh, Scotland.

Kapfudzaruwa, F., Fay, J. and Hart, T. 2017. Improved cookstoves in Africa: Explaining adoption patterns. Development Southern Africa, 34(5): 548-563.

Kosenius, A.-K., Kniivilä, M., Pitiot, M. and Horne, P. 2019. Location of forest plantations in Mozambique: Gains and losses in water, firewood and land availability. Land Use Policy, 88: 104175.

Magalhães, T. M. 2014. Análise do Sistema de Exploração dos Recursos Florestais em Moçambique. Maputo: Justiça Ambiental.

Mahumane, G. and Mulder, P. 2019. Expanding versus greening? Long-term energy and emission transitions in Mozambique. Energy Policy, 126: 145-156.

Martins, R., Cherni, J. A. and Videira, N. 2018. 2 MBio, a novel tool to encourage creative participatory conceptual design of bioenergy systems - The case of wood fuel energy systems in south Mozambique. Journal of Cleaner Production, 172:3890-3906.

Massuque, J. Z., Manjate, M. J. and and Matavel, C.E. 2019. Papel das áreas de conservação no bem-estar das comunidades locais: caso da Reserva Nacional de Niassa. Nature and Conservation, 12(1): 75-82.

Matavel, N. and Chaves, G. 2015. Caracterização do Setor de Biodiesel no Moçambique. Revista Espacios, 36(3): 12-30.

Ministério da Energia [ME]. 2013. Estratégia de Conservação e Uso Sustentável da Energia da Biomassa. Maputo: ME

Lenz, A. M., Rosa, H. A., Mercante, E., Maggi, M. F., De Souza Mendes, I., Cattani, C. E. V., Johann, J. A., Ferruzzi, Y. and Gurgacz, F. 2019. Expansion of eucalyptus en ergy plantations under a Livestock-Forestry Integration scenario for agroindustries in Western Paraná, Brazil. Ecological Indicators, 98: 39-48.

Ministério da Terra, Ambiente e Desenvolvimento Rural [MITADR]. 2018. Inventário florestal nacional. Maputo: MITADR.

Mohr, A. and Raman, S. 2013. Lessons from first generation biofuels and implications for the sustainability appraisal of second generation biofuels. Energy Policy, 63:114-122.

Mucova, S. a. R., Leal Filho, W., Azeiteiro, U. M. and Pereira, M. J. 2018. Assessment of land use and land cover changes from 1979 to 2017 and biodiversity \& land management approach in Quirimbas National Park, Northern Mozambique, Africa. Global Ecology and Conservation, 16: e00447.

Mudombi, S., Nyambane, A., Von Maltitz, G. P., Gasparatos, A., Johnson, F. X., Chenene, M. L. and Attanassov, B. 2018. User perceptions about the adoption and use of ethanol fuel and cookstoves in Maputo, Mozambique. Energy for Sustainable Development, 44, 97-108.

Murphy, R., Woods, J., Black, M. and Mcmanus, M. 2011. Global developments in the competition for land from biofuels. Food Policy, 36: S52-S61.

Mwampamba, T. H., Owen, M. and Pigaht, M. 2013. Opportunities, challenges and way forward for the charcoal briquette industry in Sub-Saharan Africa. Energy for Sustainable Development, 17 (2): 158-170.

Navarra, C. and Rodrigues, C. U. 2018. Debt, aid and poverty in Mozambique: lessons learned from the Mozambican debt crisis. The Nordic Africa Institute (NAI).

Nhamire, B. and Mosca, J. 2014. Electricidade de Moçambique: mau serviço, não transparente e politizada. Maputo: Centro de Integridade Pública Moçambique.

Owen, M., Der Plas, R. V. and Sepp, S. 2013. Can there be energy policy in Sub-Saharan Africa without biomass? Energy for Sustainable Development, 17(2): 146-152.

Renzaho, A. M. N., Kamara, J. K. and Toole, M. 2017. Biofuel production and its impact on food security in low and middle income countries: Implications for the post-2015 sustainable development goals. Renewable and Sustainable Energy Reviews, 78: 503-516.

Scrase, I., Kern, F., Lehtonen, M., Mackerron, G., Martiskainen, M., Mcgowan, F., Ockwell, D., Sauter, R., Smith, A., Sorrell, S., Wang, T. and Watson, J. 2009. Energy Policy Implications. In: SCRASE, I. \& MACKERRON, G. (eds.) Energy for the Future. London: Palgrave Macmillan.

Martinez, S., Naudeau, S. and Pereira, V. 2017. Preschool and Child Development under Extreme Poverty: Evidence from a Randomized Experiment in Rural Mozambique. Washington, DC: The World Bank.

Sedano, F., Silva, J. A., Machoco, R., Meque, C. H., Sitoe, A., Ribeiro, N., Anderson, K., Ombe, Z. A., Baule, S. and Tucker, C. 2016. The impact of charcoal production on forest degradation: a case study in Tete, Mozambique. Environmental Research Letters, 11(9): 094020.

Shenoy, M., Jain, G. and Parthasarathy, T. 2011. Indian Energy Policy an d Strategy: Pre-and Post-Copenhagen 2009. International Development Policy| Revue internationale de politique de développement, 2.

Silva, J. A., Sedano, F., Flanagan, S., Ombe, Z. A., Machoco, R., Meque, C. H., Sitoe, A., Ribeiro, N., Anderson, K., Baule, S. and Hurtt, G. 2019. Charcoal-related forest degradation dynamics in dry African woodlands: Evidence from Mozambique. Applied Geography, 107: 72-81.

Sitoe, A., Mirira, R. \& Tchaúque, F. 2007. Avaliação dos níveis de consumo da energia de biomassa nas províncias de Tete, Nampula, Zambézia, Sofala, Gaza e Maputo. Maputo, Mozambique: Ministry of Energy.

Sitoe, A., Remane, I., Ribeiro, R., Falcão, M., Mate, R., Nhamirre, J., Walker, S., Murray, L. and Joana Melo, J. 2016. Identificação e análise dos agentes e causas directas e indirectas de desmatamento e degradação florestal em Moçambique. Maputo: CEAGRE and Winrock International. 
Smith, H. E., Jones, D., Vollmer, F., Baumert, S., Ryan, C. M., Woollen, E., Lisboa, S. N., Carvalho, M., Fisher, J. A., Luz, A. C., Grundy, I. M. and Patenaude, G. 2019. Urban energy transitions and rural income generation: Sustainable opportunities for rural development through charcoal production. World Development, 113: 237-245.

Suárez, S. and Borras Jr., S. 2010. Desenvolvimento, para quem?-Impacto dos Projetos de Desenvolvimento sobre os Direitos Sociais da População Rural Moçambicana. Heidelberg, FIAN International.

Tokura, W., Matimele, H., Smit, J. and Hoffman, M. T. 2020. Long-term changes in forest cover in a global biodiversity hotspot in southern Mozambique. Bothalia - African Biodiversity \& Conservation, 50(1): 1-17.

Vasco, H. and Costa, M. 2009. Quantification and use of forest biomass residues in Maputo province, Mozambique. Biomass and Bioenergy, 33(9): 1221-1228.

Vaz, K., Storey, P., Cipriano, A., Cuamba, B., D’addario, P., Falcao, P. and Lehman, N. 2011. Green Investments In Mozambique: A Market Needs Analysis on Sustainable Energy and Environmental Performance Projects in Mozambique for Agence Française de Développement and the Bank of Mozambique. Maputo: Verde Azul and PPL International.

Vesterberg, J. 2014. Wood pellet as an alternative cooking fuel in Mozambique - emission performance of a wood gasification stove. Bachelors Thesis, Swedish University of Agricultural Sciences, Sweden.

Victor, B. 2011. Sustaining Culture with Sustainable Stoves: The Role of Tradition in Providing Clean -Burning Stoves to Developing Countries. Consilience: The Journal of Sustainable Development, 5(1): 71-95.

The World Bank [WB] 2017. Mozambique Economic Update: A Two-Speed Economy. Maputo: WB.

Wertz-Kanounnikoff, S., Falcãob, M. and Putzel, L. 2013. Facing China's demand for timber: an analysis of Mozambique's forest concession system with insights from Cabo Delgado Province. International Forestry Review, 15(3): 387-397.

Woollen, E., Ryan, C. M., Baumert, S., Vollmer, F., Grundy, I., Fisher, J., Fernando, J., Luz, A., Ribeiro, N. \& Lisb oa, S. N. 2016. Charcoal production in the Mopane woodlands of Mozambique: what are the trade-offs with other ecosystem services? Philosophical Transactions of the Royal Society B: Biological Sciences, 371:20150315. 